- помимо общепринятых уголовно-правовых норм о противодействии коррупции (взяточничество, превышение и злоупотребление должностными полномочиями, и т.п.), в отдельных странах установлена уголовная ответственность и за бездействие должностных лиц (из корыстных или иных личных побуждений), за получение должности (поста) путем обмана и за подкуп служащего, не являющегося должностным лицом;

- достаточно широко применяется конфискация, практикуется наложение ареста на средства и финансовые операции, «вызывающие подозрения»;

- помимо уголовной ответственности за коррупционные преступления, широко применяются и иные виды - дисциплинарная и административная; практикуется увольнение с лишением пенсии, льгот и предусмотренных законом надбавок, установленных для определенной категории чиновников. При этом уголовная ответственность является крайней мерой, применяемой государством за совершение каких-либо более «серьезных» коррупционных деяний, а основными видами уголовного наказания являются штраф (в достаточно значимом (крупном) размере), отстранение от должности (запрет занимать должность) и лишение свободы;

- прослеживаются тенденции к ужесточению уголовного наказания для должностных и иных публичных лиц, связанных с замещением должностей на государственной и муниципальной службе, совершивших какое-либо коррупционное преступление.

$$
* * *
$$

1. Курс уголовного права в пяти томах. Особенная часть. Том 5 / Под ред. Г.Н. Борзенкова, В.С. Комисарова. М.: ИКД «Зерцало-М», 2002. - С. 486-490.

2. У Уоловное право зарубежных стран. Общая и Особенная части: учебник / Под ред. И.Д. Козочкина. - 3-е изд., перераб. и доп. - М.: Волтерс Клувер, 2010. - С. 836-840; 955.

3. Григорьев В.А. Законодательные аспекты противодействия корруп-ции в западноевропейских странах / В.А. Григорьев // https://www.winstein.org/publ/26-1-0-1119 (дата обращения: 11.11.2021).

4. Уголовный кодекс ФРГ / Пер. и пред. А.В. Серебренниковой. - М.: ИКД «Зерцало-М», 2001. - С. 13; 191195.

5. У Угловный кодекс Австрии / Науч. ред. и вступ. статья С.В. Милюкова; пред. Генераль $\neg$ ного прокурора Австрии Э.О. Фабрици; пер. с нем. Л.С. Вихровой. - СПб.: Изд-во Юри-дический центр Пресс, 2004. - С. $332,342$.

6. Уголовное законодательство Норвегии / Науч. ред. и вступ. статья Ю.В. Голика; пер. с норв. А.В. Жмени. СПб.: Изд-во Юридический центр Пресс, 2003. - С. 258-259.

\title{
Бурносова Ю.Л. \\ Понятие и значение правила непосредственности исследования доказательств в уголовном судопроизводстве
}

Смоленский областной суд

(Россия, Смоленск)

doi: $10.18411 /$ gqws-01-2022-13

\section{Аннотация}

Изложена краткая эволюция правила непосредственности в уголовном судопроизводстве. Устав уголовного судопроизводства впервые регламентировал порядок исследования доказательств в суде первой инстанции. Он был воспринят действующим УПК РФ. Формулировка ст. 240 УПК не выражает четко самой сути рассматриваемого понятия. Рассматривается предмет и дефиниция правила непосредственности исследования доказательств. Обозначено его значение.

Ключевые слова: непосредственность, Устав уголовного

судопроизводства, Уголовно-процессуальный кодекс РФ, предмет исследования, принцип уголовного процесса, внутреннее убеждение, состязательность. 
Abstract

A brief evolution of the rule of immediacy in criminal proceedings is outlined. The charter of Criminal Proceedings for the first time regulated the procedure for examining evidence in the court of first instance. He was perceived by the current Criminal Procedure Code of the Russian Federation. The wording of Article 240 of the Criminal Procedure Code doesn't clearly express the very essence of the concept in question. The subject and definition of the rule of immediacy of the study of evidence is considered. It's meaning is indicated.

Keywords: immediacy, The charter of Criminal Procedure, Criminal Procedure Code of the Russian Federation, subject of study, the principle of criminal procedure, inner conviction, competitiveness.

Известно, что право - основной регулятор общественных отношений, представляющий собой совокупность норм. Роль права в жизни общества трудно переоценить. Ценность его состоит в том, что оно, защищая права и интересы граждан, определяет границы общественно необходимой свободы личности. Уголовнопроцессуальное право - отрасль, регулирующая деятельность по расследованию, рассмотрению и разрешению уголовных дел. Закон - это форма проявления права. В более узком смысле это нормативно-правовой акт, регулирующий правила правовой процедуры.

Рассмотрим понятие и значение такой правовой нормы как правило непосредственного исследования доказательств в уголовном судопроизводстве. С учетом того, что мы рассматриваем правило непосредственности в качестве средства познания судебных доказательств, представляется целесообразным кратко проанализировать эволюцию этого правила и составить представление об основных положениях теории доказательств, ибо знание истории обогащает опытом прошедшего, объясняет настоящее и дает возможность предсказать будущее.

Известно, что в древнейший период нашей истории судопроизводство было устное, и судьи выносили решение только на основании того, что они видели и слышали. С развитием розыскного начала уголовного процесса произошел коренной поворот в судопроизводстве. Суд с доказательствами знакомился только по следственному письменному производству, непосредственность утрачивалась. Здесь функции обвинителя, обвиняемого и судьи не были разграничены и соединялись в лице судьи. Собственно он и является единственным процессуальным субъектом. Отличительный характер этой системы заключался в том, что закон ничего решительно не предоставлял мнению судьи, но определял a priori, какую силу должно иметь каждое доказательство, так что судье оставалось только механически складывать эти доказательства и быть простым орудием и исполнителем закона, не считаясь с собственным мнением. Как видим, внутреннему убеждению судьи, при такой оценке доказательств, места не было. Указанный формализм понуждал судью принимать решение вопреки своему убеждению, ибо оно не имело никакого значения.

Так продолжалось до 1864 года, когда в Уставе уголовного судопроизводства Российской империи в ст. 625 было зафиксировано: «Судебное следствие производится изусно». Суд обязан был использовать в обоснование своего решения только то, что непосредственно исследовалось в судебном заседании. Внутреннее убеждение судьи складывается в ходе непосредственного исследования представленных сторонами судебных доказательств. Однако термин «непосредственность» не содержался в УУС. В нем использовался такой термин как «устность». Однако слово «устность» давало не совсем полное и точное понятие о той особенности судебного следствия, которую ею называют. Решили что слово «устность» лучше заменить выражением «непосредственность». Под непосредственностью доказательств понималось не какое-либо присущее им внутреннее свойство, а только прием, с соблюдением которого доказательства, какого бы содержания они не были, должны быть предъявляемы на судебном следствии.

Требования непосредственности исследования доказательств были восприняты в действующем УПК РФ. Установлено, что стороны должны участвовать в непосредственном 
исследовании имеющихся доказательств по уголовному делу, сознавая, что ни одно доказательство, не исследованное судом, не может быть положено в обоснование приговора. Это имеет фундаментальное значение для защиты прав и свобод человека.

Благодаря такому исследованию, суд получает качественную возможность составить определенное суждение о произошедшем событии, виновности (невиновности) подсудимого, решая вопросы об относимости, допустимости, достоверности и достаточности всей совокупности доказательств, в том числе и тех, которые были истребованы судом, для принятия итогового решения.

Непосредственность судебного разбирательства, в качестве общего условия этой стадии уголовного судопроизводства, регламентирована в статье 240 УПК РФ. В это понятие законодатель включает все доказательства, которые подлежат исследованию, как первоначальные, так и производные. Однако их роль в доказывании весьма различна. Указанная широкая трактовка законодателем правила непосредственности исследования доказательств на практике порой приводит к тому, что процедура судебного разбирательства в значительной своей сути сводится к ритуалу оглашения материалов уголовного дела, составленных следователем [1]. Отмеченное нарушает права на процессуальное равенство сторон в судебном процессе; права обвиняемого, не признающего вину, задавать вопросы показывающему против него свидетелю [2]. В современной уголовно-процессуальной литературе справедливо отмечается, что формулировка данной статьи не выражает четко самой сути рассматриваемого понятия [3].

Мы считаем, что предметом непосредственного исследования доказательств в суде является регламентированная законом процедура производства судебных действий, позволяющая сформировать целостное представление о содержании имеющихся доказательств и, на этой основе, получить обоснованное внутреннее убеждение судьи по обстоятельствам, подлежащим доказыванию.

Следовательно, непосредственность - это правило уголовного судопроизводства, согласно которому неизменный состав суда, путем личного восприятия в ходе состязательного судебного разбирательства, в устной форме исследует представленные стороной обвинения и защиты доказательства с участием подсудимого, его защитника, государственного обвинителя, других участников уголовного судопроизводства, для принятия законного, обоснованного и справедливого итогового решения по уголовному делу на основании сложившегося объективного внутреннего убеждения.

Из содержания правила непосредственности можно сформулировать два вывода: 1) требование личного восприятия доказательств участниками судебного следствия, исследующими и оценивающими их, с возможностью задать вопросы и оспорить информацию; 2) требование основывать итоговое решение на совокупности доказательств, исследованных лично.

Определенная группа ученых рассматривает правило непосредственности доказательств в качестве принципа уголовного процесса. Однако по данному вопросу не существует единого мнения. Первые считают, что принципы - это общие руководящие положения, на которых строится уголовный процесс. Причем принципами процесса признаются только такие, соответствующие его объективной сущности, руководящие идеи, которые получили свое закрепление в нормах права [4.]. Принципы уголовного судопроизводства - это законодательно закрепленные основополагающие правовые положения прямого действия [5.].

Однако определенный ряд ученых процессуалистов считают, что принципы в своей значительной части не могут подлежать непосредственному закреплению в тексте уголовнопроцессуального законодательства [6.].

Мы придерживаемся точки зрения, что принципы уголовного судопроизводства должны найти нормативное отражение, относится ко всему уголовному процессу, а не к части его, и поэтому не считаем непосредственность исследования доказательств принципом уголовного процесса, так как сам законодатель отнес непосредственность к общим условиям 
судебного разбирательства, предусмотрев даже определенные исключения его в случаях, предусмотренных разделом Х УПК РФ.

Следует иметь в виду, что под общими условиями судебного разбирательства принято понимать установленные законом правила, конкретизирующие и уточняющие принципы уголовного процесса применительно к судебным его стадиям. Фактически они отличаются от принципов уголовного процесса лишь меньшей степенью общности, действуя не во всех стадиях, а лишь в нескольких - в первую очередь, при рассмотрении уголовного дела в суде первой инстанции [7.].

Значение непосредственного исследования доказательств заключается в том, что в состязательном, устном и гласном процессе судья имеет возможность получать лично информацию из первых рук, учитывая противоречивые позиции сторон, независимо от того, насколько точно и объективно она отражена в следственных документах. Исследование доказательств путем проведения следственных действий в ходе судебного следствия позволяет судье, благодаря непосредственному восприятию, сформировать собственное внутреннее убеждение о предмете преступного посягательства и виновности (невиновности) подсудимого. Решающую роль в этом играет принцип свободы оценки доказательств, предусмотренный ст. 17 УПК РФ, и принцип независимости судей.

Мы считаем, что внутренне убеждение судьи - это его психическое состояние, возникшее как результат оценки доказательств, осуществленной на основании логически построенных выводов об относимости, допустимости, достоверности и достаточности совокупности доказательств, основанное на всестороннем, полном и объективном непосредственном исследовании судом фактических обстоятельств дела с учетом критического анализа позиции сторон. Внутреннее убеждение судьи, это не мимолетное мнение, а осознанное, основанное на законах психологии, логически, выверенное и обоснованное решение. Внутреннее убеждение - это убеждение совести.

Следует подчеркнуть, что непосредственность выполняет важную роль в познавательной деятельности суда, обеспечивая состязательность производства. Стороны в состязательном процессе ставятся перед необходимостью представления суду доказательств, непосредственного исследования их перед судом, в том числе и использования перекрестных методов допроса, отстаивания своей процессуальной позиции путем взаимной критики и аргументированного опровержения выводов противной стороны. Целью процессуальной деятельности каждой из сторон является доказывание суду правильности своих мотивированных выводов на основании представленных доказательств. Окончательный судебный акт выносится, когда у судьи сформировалось стойкое внутреннее убеждение и исследованные фактические обстоятельства уже не могут быть поставлены под сомнение. Европейский суд отмечает, что для итоговой оценки доказательств он обычно применяет стандарт: «вне всякого разумного сомнения» [8.].

$$
* * *
$$

1. Власова С.В., Балалаева М.В. Современный правовой формат судебного следствия // Проблемы правоохранительной деятельности. № 3. 2016. С.59.

2. Постановление Пленума Верховного Суда РФ № 21 от 27 июня 2013 г. «О применении судами общей юрисдикции Конвенции о защите прав человека и основных свобод от 4 ноября 1950 г. и Протоколов к ней».

3. Мезинов Д.А. О проблемах реализации начала непосредственности судебного разбирательства в уголовном судопроизводстве // Вестник Омского университета. Серия «Право». 2008. № 4 (17). С.178.

4. Добровольская Т.Н. Принципы советского уголовного процесса (вопросы теории и практики). М. Юридическая литература. 1971. С.175.

5. Россинский С.Б. Уголовный процесс. Учебник. М. Эксмо. 2009. С.69.

6. Агутин А.В. Мировоззренческие идеи в уголовно-процессуальном доказывании. Автореф. дисс. доктора юр. наук. Нижний Новгород. 2005. С.38.

7. Белкин А.Р. УПК РФ: конструктивная критика и возможные уточнения. Часть ХІІ. Подготовка к судебному заседанию. Общие условия судебного разбирательства. М. 2018. С.48.

8. Постановление ЕСПЧ по делу «Ирландия против Соединенного Королевства» (Ireland v. United Kingdom) от 18 января 1978 г. Доступ из справ.- правовой системы "КонсультантПлюс". 